\title{
Folic acid content and fruit characteristics of five Indonesian dessert banana cultivars
}

\author{
RITA NINGSIH ${ }^{1,2, \boldsymbol{v}}$, RITA MEGIA ${ }^{1}$ \\ ${ }^{1}$ Department of Biology, Faculty of Mathematics and Natural Sciences, Institut Pertanian Bogor. Jl. Raya Dramaga, Bogor 16680, West Java, Indonesia \\ ${ }^{2}$ Department of Biology, Faculty of Mathematics and Natural Sciences, Universitas Halu Oleo. Jl. H.E. Mokodompit, Anduonohu, Kendari 93231, \\ Southeast Sulawesi, Indonesia. Tel.: +62-401-3191929, `email: rita_unhalu@yahoo.com
}

Manuscript received: 24 September 2018. Revision accepted: 7 December 2018.

\begin{abstract}
Ningsih R, Megia R. 2019. Folic acid content and fruit characteristics of five Indonesian dessert banana cultivars. Biodiversitas 20: 144-151. Folic acid plays an important role in the many metabolic functions of organism, especially pregnant women. Whereas banana is a fruit that rich in nutrients, high productivity, high diversity, well known, and widely consumed in many countries and by various communities from infants to elderly. The research aimed to analyze folic acid content and describe the morphology of mature fruits at three different genomic groups of five Indonesian dessert banana cultivars namely Ambon Kuning (AAA), Ambon Lumut (AAA), Raja Sereh (AAB), Raja Bulu (AAB), and Lampung (AA). The folic acid content of fruit was analyzed using HPLC equipped with a UV-vis detector. Fruit characters were analyzed based on 21 descriptors then subjected to clustering analysis. The result shows that folic acid content of mature stage was $22.26 ; 21.39 ; 22.59 ; 21.2$; and $24.58 \mu \mathrm{g} / 100 \mathrm{~g}$ fresh weight for those five banana cultivars respectively. Lampung cultivar showed the highest value. Analysis of variance followed by DMRT at 5\% probability showed that folic acid, bunch weight, fruit weight, and fruit length were significantly diverse among those five cultivars. Clustering analyses revealed that two groups were formed. The first comprises of Ambon Kuning and Ambon Lumut while the second of Raja Sereh, Lampung, and Raja Bulu. Lampung cultivar was closely related to Raja Sereh than the other cultivars. Adjusted Rand Index analyzed concluded that the immature peel color, mature pulp color, and predominant taste were the best distinctive characters. This knowledge can be used as a consideration for the plant breeding program especially in nutrition improvement.
\end{abstract}

Keywords: Banana cultivar, folic acid, fruit, morphology

\section{INTRODUCTION}

Folate (Folic acid) is one of the B groups of vitamins that are essential for human health. Chemical compounds with similar chemical properties and biological activity to folic acid are recognized as folate (Verma et al. 2015). Folates participate in several metabolic functions, such as DNA methylation and the biosynthesis of amino acids (methionine, glycine, and serine), nucleic acids, and Sadenosylmethionine (SAM) (Hanson and Gregory III 2011). Folate deficiency can cause serious health issues including neural tube defect (NTDs), impaired cognitive function, and cardiovascular diseases (Geisel 2003; Ramos et al. 2005; Kolb and Petrie 2013). It is also associated with numerous neurodegenerative disorders, including Alzheimer's disease (Seshadri et al. 2002) and various cancers (Choi and Friso 2005). The Recommended Dietary Allowance (RDA) of folates is $400 \mu \mathrm{g}$ for adults and 600 $\mu \mathrm{g}$ for pregnant women (Institute of Medicine Food and Nutrition Board 1998).

The human cannot synthesize folates and thus depend upon their diet from plant and animal sources (Scott et al. 2000; Basset et al. 2005). Pulses and other legumes, as well as beef liver, spinach, asparagus, lettuce, and Brussels sprouts, are rich in folates (USDA-ARS 2012). However, to gain folate from these sources some processing steps required whereas folate character is unstable to heat. Boiling can destroy folate $30-95 \%$ from the green bean and hashed spinach (Bureau et al. 2015). Therefore, it is necessary that the alternative foodstuffs can be consumed directly without processing to obtain optimal folate such as fruit.

Banana is a fruit that is rich in nutrients, are well known and widely consumed in many countries and by various communities from infants to the elderly. Production of bananas and plantains in the world predicted to be around 125 million tons per year, ranks first rank of world fruit production (FAO 2010). National banana production in 2015 reached 7,299,275.00 tons, while consumption was 1.545.543 tons (Badan Pusat Statistik 2015; Rohmah 2016). In addition to productivity, genetic diversity of banana germplasm is very high, therefore it has great potential as a medium to address nutritional problems. Commercial bananas (cultivated) are currently thought to have come from wild banana Musa acuminata Colla ( $2 \mathrm{x}=$ 22, symbolized A) and or Musa balbisiana Colla $(2 \mathrm{x}=22$, symbolized B). Triploid cultivars dominate most of the world's banana production in the form of dessert varieties of bananas or cooking bananas included in the genome group $\mathrm{AAA}, \mathrm{AAB}$, and $\mathrm{ABB}$. $\mathrm{ABB}$ genotype is generally a cooking banana, plantain, and AAA or AAB classified as dessert banana (Karamura and Mgenzi 2004). The number of banana cultivars in the world is hard to pin down. It used to be estimated at 500 or so, but it has also been suggested that it could be twice as many (Promusa 2018). Meanwhile recorded approximately 306 accessions of banana found in 
the garden collection of International Centre for Horticultural Research and Development (ICHORD) in Solok West Sumatra Indonesia and about 250 accessions are cultivated (MGIS 2018).

Morphological characterization of mature fruits at different genomic groups is important to be conducted as it is related to the fruit identity and consumer's preferences. Hapsari and Lestari (2016) describe that each banana cultivar had specific characteristics related to their genomic group. Pisang Berlin has bright yellow peel and pulp, sugary taste. Pisang Ambon Hijau has fine curved fruit shape, sweet taste and aromatic. Pisang Raja Bandung has medium thickness and yellow peel, firm flesh, sweet and slightly acidic taste. Pisang Kepok has thick coarse and yellow peel with dark brown blotches, mildly sweet taste. Fruit characters of Pisang Berlin and Ambon Hijau are closely related to their ancestral parents' Musa acuminata wild species, whereas Pisang Kepok and Pisang Raja Bandung as hybrid cultivars have intermediate characters between Musa acuminata and Musa balbisiana wild species.

So far there is no specific scientific report about the content of folic acid (B-9 vitamin) in various genotypes of bananas. In this research, we choose five cultivars of popular Indonesian dessert bananas are Ambon Kuning (AAA), Ambon Lumut (AAA), Raja Sereh (AAB), Raja Bulu (AAB) and Lampung (AA). These five popular cultivars due to the large consumed, easy to obtained and available along the season. According to the data from University of Florida (2013), folic acid content in bananas is $20 \mu \mathrm{g} / 100 \mathrm{~g}$ fresh weight. In addition to folic acid, the information about banana fruit characteristics at different genomic groups is still lacking. The purpose of this research was to analyze the folic acid content and fruit characteristics of five popular Indonesian dessert banana cultivars.

\section{MATERIALS AND METHODS}

\section{Materials}

Five popular dessert banana cultivars of Indonesia represent three genomic banana groups were obtained from commercial plantations and small estates around Bogor district on January until March 2018 (Table 1). Three bunches from three plants per cultivar are harvested and then one or two middle hands are taken, wrapped in cardboard and labeled then allowed to mature naturally indoors at room temperature (Ekesa et al. 2015) until mature stage 6 . According to Stover and Simmonds (1987), mature stage 6 is a condition where all the fruit is yellow skin color with soft pulp texture (already ripe but not overripe).

\section{Folic acid analysis}

Folic Acid analyses of ripe banana pulp were conducted at PT Saraswanti Indo Genetech Laboratory in Duplo reactions for each sample and repeated three times. Three fingers randomly selected from the middle hands, then washed, peeled, cut into $0.5-0.7 \mathrm{~cm}$ thick longitudinal wedges, flesh-frozen in liquid nitrogen, and kept at $-80^{\circ} \mathrm{C}$ for folic acid extraction (Garcia-Salinas et al. 2016). Folic acid is extracted and purified refers to a method Rahimi and Goodarzi (2011) that has been modified. Five grams of sample into a $25 \mathrm{~mL}$ measuring flask, add $10 \mathrm{~mL}$ of phosphate buffer and $5 \mathrm{~mL}$ of acetonitrile then crush it with the phosphate buffer and homogenize. The mixture was centrifuged for 15 minutes at $8500 \mathrm{rpm}$. The supernatant was filtered through $0.45 \mu \mathrm{m}$ millipore filter then $10 \mathrm{~mL}$ filtrate was passed into the SPE. Prior to HPLC analysis, all samples were filtered through a $0.45 \mu \mathrm{m}$ millipore filter. The sample is ready to be injected. Each of the $20 \mu \mathrm{L}$ sample and standard solutions injected into HPLC under the following measurement conditions: Lichrospher RP 18 column; isocratic, mobile phase are $2 \%$ acetic acid $\mathrm{pH} 2.8$ (A) and acetonitrile (B); and $1.0 \mathrm{~mL} / \mathrm{min}$ flow rate. The Folic acid was detected with UV-vis at $\lambda 283 \mathrm{~nm}$. The folic acid content in the sample is calculated and determined using a straight-line calibration curve: $\mathrm{Y}=\mathrm{bx}+\mathrm{a}(\mathrm{PT}$ Saraswanti Indo Genetech 2013)

Folic acid content $(\mathrm{mg} / \mathrm{kg})=\underline{\text { (intercept area)/slope } \mathrm{x} \text { final volume }(\mathrm{mL}) \mathrm{x} \mathrm{df}}$ Sample weight (g)

\section{Fruit characterization}

Samples are taken from mid-hand and youngest hand of the bunch. Immature fruit characteristic recorded on the youngest hand of the bunch before maturity, meanwhile, mature fruit characteristic recorded at mature stage 6 (ripe but not overripe or full yellow stage). Morphological characterizations were conducted according to the descriptor for Banana from IPGRI (1996). Morphological descriptors about 21 characters are fruit position, number of fruit, fruit length, fruit shape, transverse section of fruit, fruit apex, remain of flower relicts at fruit apex, fruit pedicle length, fruit pedicle width, pedicle surface, fusion of pedicles before joining the crown, immature fruit peel color, mature fruit peel color, fruit peel thickness, adherence of the fruit peel, cracks in fruit peel, pulp color before maturity, pulp color at maturity, fruit fall from hands, flesh texture and predominant taste. The agronomic characters of the fruit were also recorded: fresh fruit weight (pulp, peel and total), bunch weight, number of hand/bunch, number of fruit/hand, and fruit length.

Table 1. Banana material examined in this study

\begin{tabular}{llll}
\hline Cultivar & Synonim $^{*)}$ & Genomic Group & Location $^{* *}$ ) \\
\hline Ambon Kuning & Pisang Embun, Gros Michel & AAA & Babakan, Cikalong, Cibatok \\
Ambon Lumut & Ambon Masak Hijau, Lakatan & AAA & Babakan, Bojong Jengkol, Cikalong \\
Raja Sereh & Rastali, Silk, Manzana & AAB & Babakan, Cikalong, Cibatok, \\
Raja Bulu & - & AAB & Babakan, Cibatok, Cikalong \\
Lampung & Empat puluh hari & AA & Babakan, Carang Pulang, Cibatok \\
\hline
\end{tabular}

Note: ${ }^{*}$ Source from Valmayor et al. (2000); ${ }^{* *}$ villages in Bogor district 


\section{Data analysis}

The data of folic acid content and fruit characters were analyzed by one way of analysis variance (ANOVA) using the software SPSS version 22. If there were significant differences followed by Duncan Multi-Range Test at 5\% probability. Folic acid content was also analyzed by comparing to RDA (Recommended Dietary Allowance) value both for women pregnant and adult. The fruit characters were analyzed comparative and descriptively based on 21 descriptors. All of them are analyzed using the Adjusted Rand Index (ARI) to know main characters which distinguish the cultivars. Qualitative analysis of fruit characters are first numerical quantified using the unweighted scoring method; subsequently, it is subjected to clustering analysis using software of MINITAB version 16 with paired group algorithm and Euclidean distance measure.

\section{RESULTS AND DISCUSSION}

\section{Folic acid content and agronomic characters}

Fruits of various cultivars significantly different in their folic acid content based on the analysis of variance with a $5 \%$ confidence level. The highest content of folic acid in $100 \mathrm{~g}$ of fresh fruit weight was found in Lampung cultivar $(24.58 \mu \mathrm{g})$ and significantly different from the other four cultivars based on Duncan Multi-Range Test analysis (Table 2). The lowest content of folic acid is owned by the Raja Bulu $(21.10 \mu \mathrm{g})$ and for three other cultivars from high to low are Raja Sereh $(22.59 \mu \mathrm{g})$, Ambon Kuning $(22.26 \mu \mathrm{g})$, and Ambon Lumut $(21.39 \mu \mathrm{g})$. However, the difference of folic acid content of the four cultivars is not significant. The folic acid content of local dessert banana in this study is generally higher than unknown banana cultivar from Florida Folic Acid Coalition (2017) data $(20 \mu \mathrm{g} / 100 \mathrm{~g}$ fresh weight) and also higher than apple fruit $(5.5 \mu \mathrm{g} / 100 \mathrm{~g}$ fresh weight) (Mateljan 2018). As another comparison, total folate content from eight Indian banana varieties ranges between $10-188 \mu \mathrm{g} / 100 \mathrm{~g}$ fresh weight (Akilanathan et al. 2010).

Compared with the reference value of dietary allowance (RDA, $400 \mu \mathrm{g} / 100 \mathrm{~g}$ for adult and $600 \mu \mathrm{g} / 100 \mathrm{~g}$ for pregnant women), the folic acid content in $100 \mathrm{~g}$ of fresh fruit weight in the five dessert banana cultivars is ranging from 5.3 to $6.1 \%$. Meanwhile, the content in one piece of fruit ranged from 8.16 $\mu \mathrm{g}$ in Lampung to $32.01 \mu \mathrm{g}$ in Ambon Kuning. The banana cultivars of Lampung though contain the highest folic acid $24.58 \mu \mathrm{g} / 100 \mathrm{~g}$ fresh weight, but the content in the one piece fruit is lowest due to the size of the fruit itself.

Dessert banana fruit is often consumed fresh, common folate losses due to oxidation and leaching associated with processing are not the concern (Delchier et al. 2013). Another folate source, for example, rice, wheat, potatoes, tomatoes, and the highest content of beans reaches more than $100 \mu \mathrm{g} / 100 \mathrm{~g}$ fresh weight (Jha et al. 2015). However, the disadvantage of the sources is the loss of folate due to heating and processing. Heat can destroy folate $60-70 \%$ and boiling 30-95\% from plant food material (Indrawati et al. 2004; Bureau et al. 2015). Therefore eating dessert banana is the best thing to get folate as a whole.
Table 2. Folic acid content and percentage to RDA value of five dessert banana cultivars

\begin{tabular}{lcccc}
\hline Cultivar & $\begin{array}{c}\text { Folic acid } \\
(\boldsymbol{\mu g} / \mathbf{1 0 0} \mathbf{g} \\
\mathbf{F W})\end{array}$ & $\begin{array}{c}\text { \% Folic } \\
\text { acid to } \\
\text { adult RDA } \\
\text { value }\end{array}$ & $\begin{array}{c}\text { \% Folic acid } \\
\text { to women } \\
\text { pregnant } \\
\text { RDA value }\end{array}$ & $\begin{array}{c}\text { Folic } \\
\text { acid/fruit } \\
(\boldsymbol{\mu g} / \mathbf{1 0 0} \text { g } \\
\mathbf{F W})\end{array}$ \\
\hline Ambon kuning & $22.26 \mathrm{a}$ & 5.6 & 3.7 & 32.01 \\
Ambon lumut & $21.39 \mathrm{a}$ & 5.3 & 3.6 & 15.82 \\
Raja sereh & $22.59 \mathrm{a}$ & 5.6 & 3.8 & 16.82 \\
Raja bulu & $21.10 \mathrm{a}$ & 5.3 & 3.5 & 16.59 \\
Lampung & $24.58 \mathrm{~b}$ & 6.1 & 4.1 & 8.16 \\
\hline
\end{tabular}

Note: RDA = Recommended Dietary Allowance for adult 400 $\mu \mathrm{g} / 100 \mathrm{~g} \mathrm{FW}$ and women pregnant $600 \mu \mathrm{g} / 100 \mathrm{~g}$ FW (Fresh Weight). Means with a different letter in the same column indicate statistically significant differences calculated by Duncan Multi-Range Tested $(P<0.05)$. Values are means of three independent determinations.

Besides folic acid content, Indonesian dessert bananas have good nutrition value. Hapsari and Lestari (2016) described that nutrient values of Indonesian dessert bananas from genome AAA, and AA in $100 \mathrm{~g}$ of edible portion contained high carbohydrates (16.72-35.24 g/100 $\mathrm{g})$, total sugar (12.12-20.82 g/100 g), potassium (275-375 $\mathrm{g} / 100 \mathrm{~g})$, and vitamin $\mathrm{C}(16.45-30.27 \mathrm{~g} / 100 \mathrm{~g})$; moderate protein (1.48-1.78 g/100 g), low fat (0.03-0.08 g/100 g) and high calories (73.43-148.80 calories/100 g). Due to its high nutrient values, bananas are nutritious food recommended for people at all ages, especially for baby, also diet food for adults. Other advantages of banana as a folic acid source and nutritious food are widely consumed in many countries and by various communities, affordable prices, available along the season, high productivity and genetic diversity of germplasm.

The content of folic acid in fruit can vary depending on the variety, environmental factors and methods of analysis. Presently, the most common techniques of folates analysis in food are microbial assays, ligand binding analysis, and high performance liquid chromatographic (HPLC) methods (Verma et al. 2015). In this study, we use the HPLC method with a UV-vis detector at $\lambda 283 \mathrm{~nm}$. However, the results of folic acid measurements are not too different if compared with varying values of method. According to Yon and Hyun (2003), folate content in bananas is 16 $\mu \mathrm{g} / 100 \mathrm{~g}$ using microbiological assay, whereas $20 \mu \mathrm{g} / 100 \mathrm{~g}$ from the University of Florida (2013) using HPLC method. Meanwhile, Garcia-Salinas et al. (2016) reported it amounted to $33.5 \mu \mathrm{g} / 100 \mathrm{~g}$ fresh weight.

The importance of plant foods to human folate nutrition has spurred successful efforts to increase plant folate content ('biofortification') using metabolic engineering (Beakert et al. 2008). Initial studies in tomato fruit and Arabidopsis thaliana overexpressed the first enzyme of the pteridine branch of the folate pathway GTP cyclohydrolase I (Diaz de la Garza 2004). The efforts to increase the content of folic acid in bananas is becoming important both with conventional and modern approaches in biotechnology. Besides, the exploration of folic acid content in germplasm of other banana plants is also urgent, to find cultivars/varieties that have high folic acid content. 
The superior cultivar can be adopted directly in the field or as a metabolite profile database useful for breeding programs.

The result of variance analysis showed significant differences in pulp, peel and total weight. The Ambon Kuning cultivar has the highest pulp, peel, and total $(103.95 ; 39.46 ; 143.78 \mathrm{~g})$ and the lowest of Lampung $(28.79 ; 4.32 ; 33.19$ g). As a comparison, Mas Kirana cultivar (AA) has $71.36 \mathrm{~g}$ (Prahardini et al. 2010) and Cavendish cultivar (AAA) has $180.56 \mathrm{~g}$ fresh weight of fruit, $114.54 \mathrm{~g}$ weight of pulp, $66.02 \mathrm{~g}$ weight of peel, 63.38 pulp $\%$ and $36.6 \%$ peel (Soltani et al. 2011). The weight of Ambon Kuning and Lampung cultivars differed significantly against all cultivars while the Ambon Lumut, Raja Sereh and Raja Bulu did not differ significantly from each other. Lampung cultivar has the highest proportion of pulp $(86.74 \%)$ compared to the peel of the fruit $(13.01 \%)$ followed by Ambon Kuning, Raja Sereh, Raja Bulu and lowest of Ambon Lumut (Table 3). The highlight for Lampung cultivar, it has the highest in folic acid content and $\%$ pulp to total fresh weight of fruit. In addition, bunch weight and fruit length have differed significantly among cultivars (Table 4). Ambon Kuning has the highest value while Lampung has the lowest based on bunch weight and fruit length. Fruit length is significantly different according to the three genomic group, e.g. Ambon group (AAA), Raja group (AAB), and Lampung (AA). Meanwhile, the number of hand/bunch and number of fruit/hand of all cultivars are not significantly different. The data is very necessary as a consideration in the breeding program to get a banana fruit that has high folate content with good agronomic character. Other than it is important for consumer preferences and basic scientific information for society.

\section{Fruit characteristics}

Fruit characterization revealed that each banana cultivar had specific characteristics due to their genomic group as shown in Table 5 and Figure 1. Ambon Kuning (AAA) has the largest hand and individual fruits size of all cultivars. Its fruit peel is $>3 \mathrm{~mm}$, cracked and easy fall from hand and it easy to peel. It has the yellow color of peel and ivory of pulp also sweet aromatic taste so that very popular to consumers. Ambon Lumut (AAA) has a smaller individual fruit size than Ambon Kuning. It has dark green with black spot of peel at immature then turn to yellowish-green with black spot at mature. Lampung cultivar (AA) has the smallest individual fruit size of cultivars. Its fruit peel is very thin and easy to fall from hand with light green color at immature then turn bright yellow at mature. It has the cream color of immature pulp and turns yellow, sugary taste and the straight rounded transverse section of fruit. These three cultivars are favorite dessert bananas in Indonesia that have the similar 'ancestral parents' wild seeded M. acuminata species (Table 5; Figure 1).

Raja Sereh and Raja Bulu from the genomic group $\mathrm{AAB}$ show the differences characteristics in fruit position and fruit apex with the both Ambon cultivars (AAA). The Raja cultivars have the curved fruit position and bottlenecked apex while Ambon cultivars have perpendicular to the stalk and pointed apex. Other than the individual fruit size of them are smaller than Ambon cultivars. Raja Sereh has rounded of the transverse section of fruit and partially fused of pedicles before joining crown. It has thin and green with black spot color of immature peel then turning bright yellow at mature. The immature pulp color is white then turning cream at mature with sweet and acidic taste. Raja Bulu has slightly ridge of the transverse section of fruit, persistent and very partially of pedicles before joining crown. It has medium thick and dark green color of immature peel then turning yellow at mature. Differ from Raja Sereh, it has the ivory color of pulp before maturity then turning yellow with sugary taste at mature. Both of them are also popular dessert banana in Indonesia from "hybrid ancestral parents" (M. acuminata $x$ M. balbisiana).

The basic characteristic of banana of AA group is small size with attractive golden-yellow thin peel, light orange and soft pulp, predominant sweet taste (slightly sour) and aromatic fragrance. Bananas AAA group are more vigorous than the diploids and bear heavy, symmetrical bunches of large fruit and markedly curved with creamy white to the yellow pulp, soft and fine textured, sweet taste with aromatic flavor. Fruit of AAB group bananas are characterized by its large fruit with thick coarse peel, orange; pulp creamy-orange, coarse texture and sweet tastes (Daniells et al. 2001; Espino et al. 1992; Hapsari 2013; Hapsari and Masrum 2011; Simmonds 1959; Vargas and Sandoval 2005).

Table 3. Fruit fresh weight of five dessert banana cultivars

\begin{tabular}{lccccc}
\hline Cultivar & Pulp (g) & Peel (g) & $\begin{array}{c}\text { Total } \\
\text { (g) }\end{array}$ & $\begin{array}{c}\text { \% } \\
\text { Pulp/ } \\
\text { total }\end{array}$ & $\begin{array}{c}\text { \% Peel/ } \\
\text { total }\end{array}$ \\
\hline Ambon kuning & $103.95 \mathrm{a}$ & $39.46 \mathrm{a}$ & $143.78 \mathrm{a}$ & 72.30 & 27.44 \\
Ambon lumut & $50.13 \mathrm{~b}$ & $23.83 \mathrm{~b}$ & $73.95 \mathrm{~b}$ & 67.79 & 32.22 \\
Raja sereh & $56.62 \mathrm{~b}$ & $17.25 \mathrm{~b}$ & $74.45 \mathrm{~b}$ & 76.05 & 23.17 \\
Raja bulu & $54.54 \mathrm{~b}$ & $24.06 \mathrm{~b}$ & $78.63 \mathrm{~b}$ & 69.36 & 30.60 \\
Lampung & $28.79 \mathrm{c}$ & $4.32 \mathrm{c}$ & $33.19 \mathrm{c}$ & 86.74 & 13.01 \\
\hline
\end{tabular}

Note: Means with the different letter in the same column indicate statistically significant differences calculated by Duncan MultiRange Tested $(\mathrm{P}<0.05)$. Values are means of three independent determinations.

Table 4. Fruit agronomic characteristics of five dessert banana cultivars

\begin{tabular}{lcclc}
\hline Cultivar & $\begin{array}{c}\text { Bunch } \\
\text { weight } \\
\text { (kg) }\end{array}$ & $\begin{array}{c}\text { Number } \\
\text { of hand/ } \\
\text { bunch }\end{array}$ & $\begin{array}{c}\text { Number } \\
\text { of } \\
\text { fruit/hand }\end{array}$ & $\begin{array}{c}\text { Fruit } \\
\text { length } \\
\text { (cm) }\end{array}$ \\
\hline Ambon kuning & $24.63 \mathrm{a}$ & $9.00 \mathrm{a}$ & $15.67 \mathrm{a}$ & $16.43 \mathrm{a}$ \\
Ambon lumut & $13.30 \mathrm{~b}$ & $7.00 \mathrm{a}$ & $12.67 \mathrm{a}$ & $13.03 \mathrm{a}$ \\
Raja sereh & $5.35 \mathrm{bc}$ & $6.00 \mathrm{a}$ & $12.67 \mathrm{a}$ & $10.63 \mathrm{~b}$ \\
Raja bulu & $12.77 \mathrm{~b}$ & $9.00 \mathrm{a}$ & $14.00 \mathrm{a}$ & $11.30 \mathrm{~b}$ \\
Lampung & $3.35 \mathrm{c}$ & $8.00 \mathrm{a}$ & $15.33 \mathrm{a}$ & $8.37 \mathrm{c}$ \\
\hline
\end{tabular}

Note: Means with the different letter in the same column indicate statistically significant differences calculated by Duncan MultiRange Tested $(\mathrm{P}<0.05)$. Values are means of three independent determinations 
Table 5. Fruit morphological characteristics of five dessert banana cultivars

\begin{tabular}{|c|c|c|c|c|c|c|}
\hline Code & Character & $\begin{array}{l}\text { Ambon Kuning } \\
\text { (AAA) }\end{array}$ & $\begin{array}{l}\text { Ambon Lumut } \\
\text { (AAA) }\end{array}$ & $\begin{array}{l}\text { Raja Sereh } \\
\text { (AAB) }\end{array}$ & $\begin{array}{l}\text { Raja Bulu } \\
\text { (AAB) }\end{array}$ & Lampung (AA) \\
\hline $\mathrm{C} 1$ & Fruit position & $\begin{array}{l}\text { Perpendicular to } \\
\text { the stalk }\end{array}$ & $\begin{array}{l}\text { Perpendicular to } \\
\text { the stalk }\end{array}$ & $\begin{array}{l}\text { Curved upward } \\
\text { (obliquely at a } 45^{\circ} \\
\text { angle upward) }\end{array}$ & $\begin{array}{l}\text { Curved toward } \\
\text { stalk }\end{array}$ & $\begin{array}{l}\text { Parallel or } \\
\text { curved towards } \\
\text { stalk }\end{array}$ \\
\hline $\mathrm{C} 2$ & Number of fruit per hand & $13-16$ & $13-16$ & $13-16$ or $\leq 12$ & $13-16$ or $\leq 12$ & $13-16$ or $\geq 17$ \\
\hline $\mathrm{C} 3$ & Fruit length $(\mathrm{cm})$ & $16-20$ & $\leq 15$ or $16-20$ & $\leq 15$ & $\leq 15$ & $\leq 15$ \\
\hline $\mathrm{C} 4$ & Fruit shape & Curved & $\bar{C}$ Curved & Curved & Curved & $\overline{\text { Straight }}$ \\
\hline $\mathrm{C} 5$ & Transverse section of fruit & Slightly ridged & Slightly ridged & Rounded & Slightly ridged & Rounded \\
\hline C6 & Fruit apex & Pointed & Pointed & Bottle-necked & Bottle-necked & Bottle-necked \\
\hline $\mathrm{C} 7$ & $\begin{array}{l}\text { Remain of flower relicts } \\
\text { at fruit apex }\end{array}$ & $\begin{array}{l}\text { Base of the style } \\
\text { prominent }\end{array}$ & $\begin{array}{l}\text { Base of the style } \\
\text { prominent }\end{array}$ & $\begin{array}{l}\text { Base of the style } \\
\text { prominent }\end{array}$ & $\begin{array}{l}\text { Base of the style } \\
\text { prominent }\end{array}$ & $\begin{array}{l}\text { Base of the style } \\
\text { prominent }\end{array}$ \\
\hline C8 & Fruit pedicel length (mm) & $<10$ & $11-20$ & $11-20$ & $11-20$ & $<10$ \\
\hline C9 & Fruit pedicel width $(\mathrm{mm})$ & $5-10$ & $5-10$ or $>10$ & $5-10$ & $5-10$ or $>10$ & $5-10$ \\
\hline $\mathrm{C} 10$ & Pedicel surface & Hairless & Hairless & Hairless & Hairless & Hairless \\
\hline $\mathrm{C} 11$ & $\begin{array}{l}\text { Fusion of pedicels before } \\
\text { joining the crown }\end{array}$ & very partially & very partially & Partially fused & very partially & Very partially \\
\hline $\mathrm{C} 12$ & Immature fruit peel color & Green & $\begin{array}{l}\text { Dark green with } \\
\text { black spot }\end{array}$ & $\begin{array}{l}\text { Green with black } \\
\text { spot }\end{array}$ & Dark green & Light green \\
\hline $\mathrm{C} 13$ & Mature fruit peel color & yellow & $\begin{array}{l}\text { Yellowish green } \\
\text { with black spot }\end{array}$ & $\begin{array}{l}\text { Bright yellow } \\
\text { with black spot }\end{array}$ & Yellow & Bright yellow \\
\hline $\mathrm{C} 14$ & Fruit peel thickness (mm) & $>3$ & $>3$ & $<2$ & $>3$ & $<2$ \\
\hline $\mathrm{C} 15$ & $\begin{array}{l}\text { Adherence of the fruit } \\
\text { peel }\end{array}$ & $\begin{array}{l}\text { Fruit peels } \\
\text { easily }\end{array}$ & $\begin{array}{l}\text { Fruit peels } \\
\text { easily }\end{array}$ & Fruit peels easily & $\begin{array}{l}\text { Fruit peels } \\
\text { easily }\end{array}$ & $\begin{array}{l}\text { Fruit peels } \\
\text { easily }\end{array}$ \\
\hline $\mathrm{C} 16$ & Cracks in fruit peel & Cracked & Without cracks & Cracked & Without cracks & Cracked \\
\hline $\mathrm{C} 17$ & Pulp color before maturity & cream & cream & White & Ivory & Cream \\
\hline $\mathrm{C} 18$ & Pulp color at maturity & Ivory & Ivory & Cream & yellow & Yellow \\
\hline C19 & Fruit fall from hands & Deciduous & Deciduous & Deciduous & Persistent & Deciduous \\
\hline $\mathrm{C} 20$ & Flesh texture & Soft & Soft & Soft & Soft & Soft \\
\hline $\mathrm{C} 21$ & Predominant taste & $\begin{array}{l}\text { Sugary, } \\
\text { aromatic }\end{array}$ & $\begin{array}{l}\text { Sugary, } \\
\text { aromatic }\end{array}$ & Sweet and acidic & Sugary & Sugary \\
\hline
\end{tabular}

Table 6. Adjusted Rand Index (ARI) of 21 fruit morphological characters from five dessert banana cultivars

\begin{tabular}{llc}
\hline Code & \multicolumn{1}{c}{ Description } & $\begin{array}{c}\text { Adjusted } \\
\text { Rand Index } \\
\text { (ARI) }\end{array}$ \\
\hline C13 & Mature fruit peel color & 0.857 \\
C18 & Pulp color at maturity & 0.857 \\
C21 & Predominant taste & 0.857 \\
C01 & Fruit position & 0.800 \\
C06 & Fruit apex & 0.800 \\
C08 & Fruit pedicel length (mm) & 0.800 \\
C12 & Immature fruit peel color & 0.800 \\
C03 & Fruit length (cm) & 0.724 \\
C14 & Fruit peel thickness (mm) & 0.724 \\
C05 & Transverse section of fruit & 0.714 \\
C17 & Pulp color before maturity & 0.714 \\
C19 & Fruits fall from hands & 0.714 \\
C04 & Fruit shape & 0.524 \\
C11 & Fusion of pedicels & 0.524 \\
C16 & Cracks in fruit peel & 0.524 \\
C02 & Number of fruits & 0.486 \\
C09 & Fruit pedicel width (mm) & 0.486 \\
C07 & Remain of flower relicts at fruit apex & NA \\
C10 & Pedicel surface & NA \\
C15 & Adherence of the fruit peel & NA \\
C20 & Flesh texture & NA \\
\hline N0t &
\end{tabular}

During the fruit ripening process, a series of changes occur physiologically, biochemically and morphologically. Morphological characters of peel color, and fruit flesh on the five varieties of bananas change during maturation. In general, fruit peel changes color from green to yellow except the variety of Ambon Lumut. Its banana skin color turns from dark green with black spot to yellowish green with black spot. The pulp color before maturity is quite varied, ranging from white, cream to ivory, while when maturity turns into cream, ivory to yellow. In addition to the ripening process, variations in some morphological characters are also influenced by the types of varieties as shown in Table 5 and Figures 1.

Differences in fruit characters among the five cultivars can be seen easily by farmers, researcher or any public interest with bananas. But not so for the common people, often appear confusion in determining the type of a banana when shopping. In addition, fruit morphological information is needed by agribusiness entrepreneurs, food industry managers, researchers who are involved in the field of plant breeding, agronomy, post-harvest processing, and biotechnology. Adjusted Rand Index (ARI) analyzed to 21 descriptors was carried out to find out the distinguishing characters among those five cultivars (Table 6). 


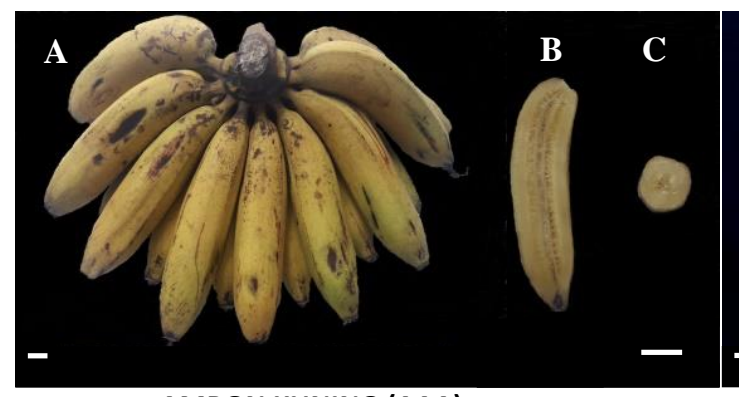

AMBON KUNING (AAA)

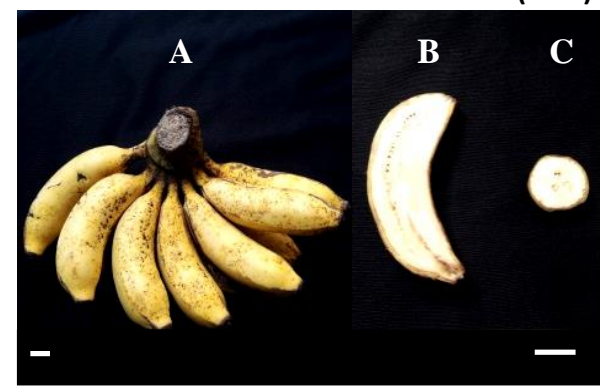

RAJA SEREH (AAB)

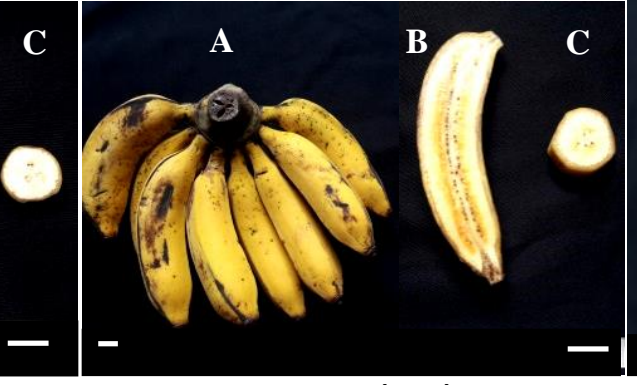

RAJA BULU (AAB)

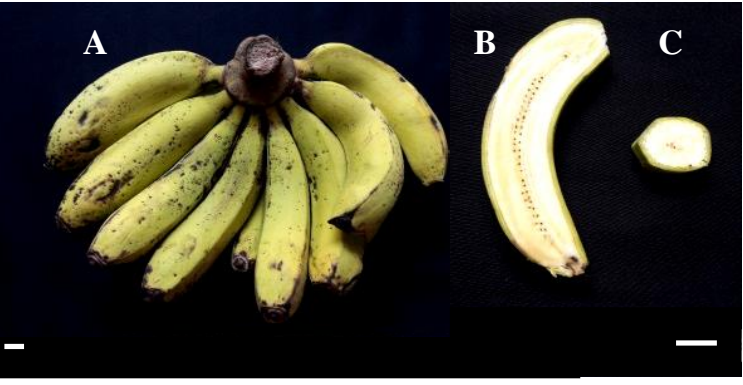

AMBON LUMUT (AAA)

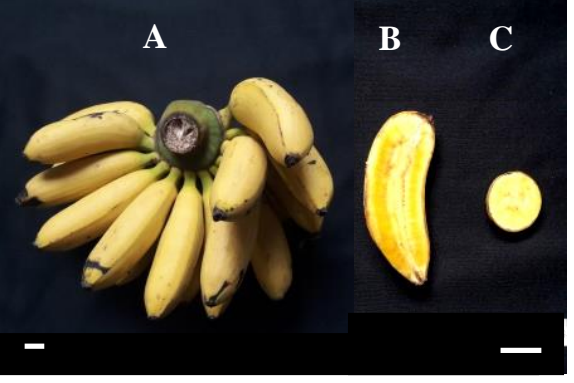

LAMPUNG (AA)

Figure 1. Mature fruit morphological characteristics of five Indonesian dessert banana cultivars: A. A hand of fruit, B. Fruit longitudinal section, C. Fruit cross section. Bar $=2 \mathrm{~cm}$

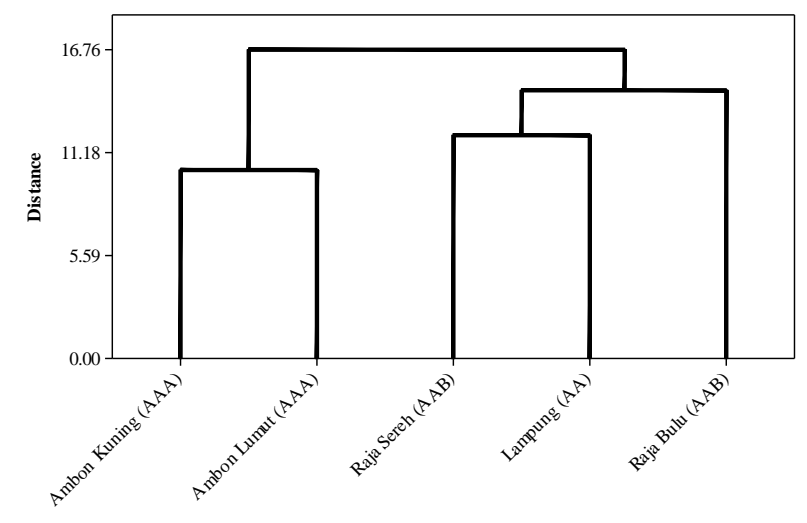

Figure 2. Dendrogram clustering analysis based on fruit morphological characters

The results show that there are three best characters as differentiator, e.g., mature fruit peel color (C13), pulp color at maturity $(\mathrm{C} 18)$, and predominant taste $(\mathrm{C} 21)$. ARI value of the three characters is close to one $(0.857)$, which means that all show considerable similarity to the reference cluster. In addition, the fruit position (C1), fruit apex (C6), fruit pedicel length (C8), and immature fruit peel color (C12) are quite good as distinguishing characteristics (Table 6). It can be seen in Table 5 and Figure 1 that C13 (mature fruit peel color) character is varied. Similarly, C18 (pulp color at maturity) and $\mathrm{C} 21$ (predominant taste) are quite different. The $\mathrm{C} 07, \mathrm{C} 10, \mathrm{C} 15$, and $\mathrm{C} 20$ are not different from each other on the five cultivars so they can't be used as distinguishing characters.

\section{Clustering analysis}

The fruit characters of Ambon Kuning (AAA) and Ambon Lumut (AAA) were closely related to their 'ancestral parent' wild seeded $M$. acuminata species. Phenotypic variation of fruit character is a qualitative trait that very much affected by genetic factor inherited from the parental. There are some other banana cultivars in which included as AAA genomic group, e.g., Ambon Badak, Ambon Putih, Ambon Hijau, Ambon Hong, Udang, Angleng, Ampyang, Nona, Santen, Williams, Byok, Kayu, Kreas, etc. (Valmayor et al. 2000; Hapsari 2013).

Raja Sereh (AAB) and Raja Bulu (AAB) as hybrid cultivars have intermediate characters between two ancestral parents' wild seeded species $M$. acuminata and $M$. balbisiana. They are much closely related to $M$. acuminata than $M$. balbisiana since it contained two 'A' genomes. Other banana cultivars that have AAB genomic group, e.g. Keling, Longong, Seribu, Tanduk, Nangka, Agung (Valmayor et al. 2000). Not all AAB genomic group has functioned as dessert banana but some other as cooking banana (plantain), i.e. Raja Nangka, Raja Kasman, Raja Marto, Raja Puser, Rojomolo, Tanduk, Tanduk Hijau, Austroli, etc (Retnoningsih et al. 2010).

Cluster analysis revealed that its fruit characters clustered according to its genome constitution. It was clustered into two groups. Ambon Kuning (AAA) was clustered together with Ambon Lumut (AAA) as group 1 with taxonomic distance 10.2 whereas Raja Sereh (AAB) was clustered together with Raja Bulu (AAB) as group 2 with taxonomic distance 14.5. Interestingly, Lampung (AA) was clustered with Raja Sereh (AAB) with taxonomic distance 12.08 exactly between Raja Sereh and Raja Bulu. Both groups were separated with taxonomic distance about 16.76 (Figure 2). Lampung cultivar (AA) was separated 
from AAA genomic group and much closer to Raja Sereh (AAB) according to four characters e.g fruit length, fruit apex, mature fruit peel color, and fruit peel thickness. Opposite to result of Hapsari and Lestari (2016) Berlin cultivar (AA) and Ambon Hijau (AAA) were together in the same group when compared with cultivars from $A B B$ genomic group. It can be explained that Hapsari and Lestari analyze AA, AAA and ABB genomic groups, while in this research investigate $\mathrm{AA}, \mathrm{AAA}$, and $\mathrm{AAB}$ genomic groups. Therefore some of the fruit morphological characters analyzed are very different.

In conclusion, the folic acid content of five Indonesia popular dessert banana cultivars is ranging from 22.26$24.58 \mu \mathrm{g} / 100 \mathrm{~g}$ fresh weight. Lampung cultivar shows the highest of folic acid content. Its content averages about $6.15 \%$ of the RDA value for adults and $4.10 \%$ for women pregnant. Fruit characters Ambon Kuning (AAA) and Ambon Lumut (AAA) were closely related to their ancestral parents' $M$. acuminata wild Species, whereas Raja Sereh (AAB) and Raja Bulu (AAB) have intermediate characters between $M$. acuminata and M. balbisiana wild species. Lampung (AA) was closely related to hybrid genome $(\mathrm{AAB})$ cultivar. There are three morphological characters are good enough to distinguish them: mature fruit peel color, pulp color at maturity and predominant taste. Those Five cultivars of Indonesian dessert bananas have a good nutrition value as a source of folic acid. They have great potential as a medium to address nutritional problems especially folic acid deficiency. Further study of folic analysis to more samples of other Indonesian banana cultivars followed by selection will support the banana breeding program to find cultivars that have higher folic acid content.

\section{REFERENCES}

Akilanathan L, Vishnumohan S, Arcot J, Uthila L, Ramachandran S 2010. Total folate: diversity between fruit varieties commonly consumed in India. Intl J Food Sci Nutr 61 (5): 463-472.

Badan Pusat Statistik. 2015. Statistik Tanaman Buah-buahan dan Sayuran Tahunan Indonesia. Badan Pusat Statistik Indonesia, Jakarta. [Indonesian]

Basset GJC, Quinlivan EP, Gregory III JF, Hanson AD. 2005. Folate synthesis and metabolism in plants and prospects for biofortification. Crop Sci 45: 449-453.

Beakert S, Storozhenko S, Mehrshahi P, Bennett MJ, Lambert W, Gregory JF III, Schubert K, Hugenholtz J, van der Straeten D, Hanson AD. 2008. Folate biofortification in food plants. Trends Plant Sci 13: 2835.

Bureau S, Mouhoubi S, Touloumet L, Garcia C, Moreau F, Bedouet V, Renard CMGC.2015. Are folates, carotenoids, and vitamin affected by cooking? Four domestic procedures are compared on a large diversity of frozen vegetables. LWT-Food Sci Technol 64: 735-741.

Choi SW, Friso S. 2005. Interaction between folate and aging for carcinogenesis. Clin Chem Lab Med 43: 1151-1157.

Daniells J, Jenny C, Karamura D, Tomekpe K. 2001. Musalogue: A catalogue of Musa germplasm. Diversity in the genus Musa. International Network for the Improvement of Banana and Plantain. Montpellier, France.

Delchier N, Ringling C, Le Grandois J, Aoude-werner D, Galland R, George S, Rychlik M, Renard CMGC. 2013. Effects of industrial processing on folate content in green vegetables. Food Chem 139 (14): $815-824$

Diaz de la Garza R, Quinlivan EP, Klaus SMJ, Basset GJC, Gregory III JF, Hanson AD. 2004. Folate biofortification in tomatoes by engineering the pteridine branch of folate synthesis. Proc Natl Acad Sci USA 101: 13720-13725.

Ekesa B, Nabuuma D, Blomme G, Bergh IV. 2015. Provitamin A carotenoid content of unripe and ripe banana cultivars for potential adoption in eastern Africa. J Food Compos Anal. 43: 1-6. DOI: 10/1016/j.jfca.2015.04.003.

Espino RRC, Jamaludin SH, Silayoi B, Nasution RE. 1992. Musa L. (edible cultivars). In: Verheij EWM, Coronel RE (eds.). Plant Resources of South-East Asia. No. 2, Edible Fruits and Nuts. Pudoc, Wageningen, Netherlands.

Florida Folic Acid Coalition. 2017. Food Chart. Available on: http: //www.folicacidnow.net/folic_acid/food_chart.shtml. [21 September 2018].

Food and Agricultural Organization of the United Nations (FAO). 2010. Available on: www.faostat.fao.org/site/340/default.aspx

Garcia-Salinas C, Ramos-Parra PA, Diaz De La Garza RI. 2016. Ethylene treatment induces changes in folate profiles in climacteric fruit during postharvest ripening. Postharvest Biol Technol 118: 43-50.

Geisel J. 2003. Folic acid and neural tube defects in pregnancy - a review. J Perinat Neonat Nurs 17: 268-279.

Hanson AD, Gregory JF. 2011. Folate biosynthesis, turnover, and transport in plants. Ann Rev Plant Biol 62: 105-125.

Hapsari L, Lestari DA. 2016. Fruit characteristics and nutrient values of four Indonesian Banana Cultivars (Musa spp.) at different Genomic Groups. Agrivita J Agr Sci 38 (3): 303-311.

Hapsari L. 2011. Keragaman dan karakteristik pisang (Musa acuminata) kultivar grup diploid AA koleksi Kebun Raya Purwodadi. In: Widyatmoko D, Puspitaningtyas DM, Hendrian R, Irawati, Fijridiyanto IA, Witono JR, Risna RA, Ariati SR, Rahayu S, Praptosuwiryo TNg. (eds.). Konservasi Tumbuhan Tropika: Kondisi Terkini dan Tantangan ke Depan. Proceedings of Seminar Cibodas Botanic Garden 159th Anniversary, Cibodas. Indonesian Institute of Sciences, Cibodas. [Indonesian]

Hapsari L. 2013. Performance of seven accessions banana cultivars triploid Musa acuminate group (AAA) collection of Purwodadi Botanic Garden. In Scheer H, Pradhan B, Brotosudarmo THP, Sadtono E, Ane BK. (Eds.). Paper presented at Proceedings of Humboldt Kolleg: Synergy, Networking and the Role of Fundamental Research Development in ASEAN, in conduction with: The International Conference on Natural Science (ICONS). 2011, Batu, Jawa Timur.

Indrawati, Arroqui C, Messagie I, Nguyen MT, Van Loey A, Hendrickx M. 2004. Comparative study on pressure and temperature stability of 5-methyl tetrahydrofolic acid in model systems and in food products. J Agric Food Chem 52: 485-492.

Institute of Medicine, Food, and Nutrition Board. 1998. Dietary Reference Intakes: Thiamin, Riboflavin, Niacin, Vitamin B6, Folate, Vitamin B12, Pantothenic Acid, Biotin, and Choline External Link Icon. National Academy Press, Washington DC.

IPGRI. 1996. Descriptors for banana (Musa spp.). International Plant Genetic Resources Institute (IPGRI), FAO $<$ Rome.

Jha AB, Kaliyaperumal A, Diapari M, Ambrose SJ, Zhang H, Tar'an B, Bet KE, Vandenberg A, Warkentin TD, Purves RW. 2015. Genetic diversity of folate profiles in seeds of common bean, lentil, chickpea, and pea. J Food Compos Anal 42: 134-140.

Karamura, Mgenzi B. 2004. On-farm conservation of Musa diversity in the Great Lakes region of East Africa. Afr Crop Sci J 12 (1): 75-83.

Kolb AF, Petrie L. 2013. Folate deficiency enhances the inflammatory response of macrophages. Mol Immunol 54: 164-172.

Mateljan G. 2018. Apple in-depth nutrient profile. Available on: http: //www. whfoods.com/genpage.php?tname=nutrientprofile $\&$ dbid=94.

MGIS. 2018. Accessions Collection of International Centre for Horticultural Research and Development (ICHORD). https://www.crop-diversity.org/mgis/collection/01IDN150

Prahardini PER, Yuniarti, Krismawati A. 2010. Karakterisasi pisang unggul Mas Kirana dan Agung Semeru di Kabupaten Lumajang. Buletin Plasma Nutfah 16 (2): 126-133. [Indonesian]

Promusa. 2018. Diversity of banana cultivars. Available on: http: //www.promusa.org/Diversity+of+banana+cultivars+portal

PT Saraswanti Indo Genetech. 2013. Diagram alir metode pengujian asam folat metode HPLC dan UPLC. Instruksi Kerja No. Instruksi 18-538/MU/SMM-SIG. PT Saraswanti Indo Genetech, Bogor. [Indonesian]

Rahimi R, Goodarzi N. 2011. Determination of folic acid in mint vegetable by High-Performance Liquid Chromatography. Org Chem J $1: 31-35$ 
Ramos MI, Allen LH, Mungas DM, Jagust WJ, Haan MN, Green R, Miller JW. 2005. Low folate status is associated with impaired cognitive function and dementia in the Sacramento Area Latino Study on Aging. Am J Clin Nutr 82: 1346-1352.

Retnoningsih A, Megia R, Hartana A. 2010. Molecular verification and diversity analysis of Indonesian $\mathrm{BB}, \mathrm{AAB}$ and $\mathrm{ABB}$ banana cultivars. Tree For Sci Biotechnol 4 (1): 69-76.

Rohmah Y. 2016. Outlook Komoditas Pisang. Pusat Data dan Sistem Informasi Pertanian. Kementerian Pertanian. Jakarta. [Indonesian]

Scott J, Rebeille F, Fletcher J. 2000. Folic acid and folate: the feasibility for nutritional enhancement in plant foods. J Sci Food Agric 80: 795824

Seshadri S, Beiser A, Selhub J, Jacques PF, Rosenberg LH, D'Agostino RB, Wilson PWF, Wolf PA. 2002. Plasma homocysteine as a risk factor for dementia and Alzheimer's disease. N Engl J Med 346: 476 483.

Simmonds NW. 1959. Bananas. Longmans Green and Co., London.

Soltani M, Alimardani R, Omid M. 2011. Some physical properties of full-ripe banana fruit (Cavendish variety). Intl J Agr Sci Res Technol $1(1): 1-5$.
Stover NW, Simmonds RH. 1987. Bananas. Longman Inc., England.

USDA ARS 2012. USDA National Nutrient Database for Standard Reference, Release 25, Nutrient Data Laboratory. United State Department of Agriculture, Agricultural Research Service, Washington, DC. Available on: http://www.ars.usda.gov/ba/nhnrc/ndl.

Valmayor RV, Jamaluddin SH, Silayoi B, Kusumo S, Danh LD, Pascua OC, Espino RRC. 2000. Banana cultivar names and synonyms in Southeast Asia. International Network for the improvement of Banana and Plantain-Asia and the Pacific office, Los Banos.

Vargas A. Sandoval J A. 2005. Agronomic evaluation of production and quality of 'Yangambi km 5' (AAA) and 'Dátil' (AA). Info Musa. 14 (1): 6-10.

Verma AK, Pandey AK, Dubey NK. 2015. Physico-chemical characteristics, analytics, and metabolism of folate in plants. J Food Process Technol 7 (1): 1-7.

Yon M, Hyun TH. 2003. Folate content of foods commonly consumed in Korea measured after tri-enzyme extraction. Nutr Res 23: 735-746. 